\title{
Analysis of the Contract System Functioning Effectiveness
}

\author{
Latysheva V.M. \\ State Financial Control Committee of St. Petersburg, \\ Saint Petersburg, Russia, \\ vera_ch23@mail.ru \\ Postnikova L.V. \\ Russian State Agrarian University - \\ Moscow Timiryazev Agricultural Academy, \\ Moscow, Russia, \\ lpostnokova@rgau-msha.ru
}

\author{
Postnikova D.D. \\ Russian State Agrarian University - \\ Moscow Timiryazev Agricultural Academy, \\ Moscow, Russia, \\ dpostnokova@rgau-msha.ru
}

Kovaleva N.N.

Ivan Petrovsky Bryansk State University, Bryansk, Russia,

Kovaleva-nat@yandex.ru

\author{
Ivanova O.P. \\ Yaroslav-the-Wise Novgorod State University, \\ Veliky Novgorod, Russia, \\ prof-ivanova@mail.ru
}

\begin{abstract}
The article deals with the relevant topic of economic research of the contract system functioning effectiveness in the field of procurement (on the example of Oryol region). The study of the contract system effectiveness is of interest within determining the effectiveness of both enterprises and their associations (clusters, in particular) functioning. Currently, the issues of public procurement discussed by the authors in the article are important for the region's socioeconomic development, since the state order covers all spheres of the economy and provides society with the necessary goods, works and services. In the article, the authors have analyzed information collected from publicly available official sources. The structure of procurement to meet the needs of the region in 2019 by procurement methods was considered, information on government contracts concluded based on the results of procurement to meet the needs of the region was studied, the value of concluded contracts and budget savings following the bidding results, as well as the value of procurement and budget savings according to the product range were analyzed. The authors pay special attention to the analysis of the amount of savings on food products. The results obtained are of practical importance and contribute to the development of economic relations in the area of procurement in the region.
\end{abstract}

Keywords-public procurement, contract, electronic auction, procurement monitoring, budget savings, contract system efficiency

\section{INTRODUCTION}

At present, in the Russian Federation, the government makes decisions and sets tasks aimed at the global, breakthrough socio-economic development of the country as a whole [1]. The key areas of development are ensuring budgetary policy, transparency of the public procurement system and openness of the budget process [2].

The creation of a new model of economic growth and its sustainable development can be achieved with the determining factors implementation using international best practices, for the further improvement of the Russian economy [3, 4].

For our research, it is of interest to consider the contract system in the field of procurement as a factor in the economy development and further improvement. As the foreign experience shows, the economy development is achieved by using modern innovations, while public procurement plays a stimulating role in the innovation process $[5,6]$.

The accumulated foreign experience, in particular the high development of the contract system in the USA [7], as well as the Federal acquisition regulation in force since 1984 [8], is of great importance for constructing the theory and practice of the domestic contract system in the field of procurement.

In our country, the contract system in the field of procurement is operated in accordance with the requirements established by the Federal Law dated April 5, 2013 No 44-FZ "On the contract system in the field of procurement of goods, works, services for state and municipal needs", which provides open access to information on the procurement of goods, performance of work, provision of services for state and municipal needs in a unified information system in the field of 
procurement.

The contract system in the field of procurement is of great importance for the state, the state order covers all economy spheres, and through the state procurement system, the state ensures the society needs for necessary goods, works and services.

The purpose of this work is to analyze the contract system functioning effectiveness in the field of procurement in Oryol region, to review the structure of procurement of goods, performance of work, provision of services to meet the needs of Oryol region in 2019, as well as the value of concluded contracts and budget savings based on the results of the bidding for ensuring the state needs of Oryol region in dynamics.

\section{FINDINGS}

Information support of the contract system in the field of procurement is carried out on the official website of the Unified Information System in the field of procurement, where all information on procurement is collected and is publicly available for bidders, as well as inspection bodies, when carrying out verification activities for the compliance of procurement with the established legal requirements.

Therefore, according to the official data presented in the consolidated analytical report on the results of monitoring the procurement of goods, works, services to meet state and municipal needs at the end of 2019, 326306 procurement participants were registered in the Russian Federation, 137988 procurement plans were posted. The total amount of financial support indicated in the procurement plans amounted to 8.24 trillion rubles. In 2019, the total annual procurement volume indicated by all customers in the schedules was 7.3 trillion rubles, which is $88.5 \%$ of the total volume of financial security. During the reporting period, 2.96 million notifications have been published in the Unified Information System, the IMCP amount of which has amounted to 9.6 trillion rubles, customers have concluded and placed in the contracts register 3.6 million contracts for a total amount of 8.21 trillion rubles [9]. State purchases are carried out by the state within the implementation of federal and regional state programs and national projects with a fixed amount of funding, performing an important function for the development of all industries in general.

Based on the Decree of the Government of Oryol Region dated September 13, 2019 No 522 "On monitoring the procurement of goods, works, services to meet the state needs of Oryol Region", the information on procurement monitoring is placed in the "State Order of the Oryol Region" automated information system by the Public Procurement Office of the Department for Economic Development and Investment Activity of Oryol Region [10].

At present, the work on improving the contract system is underway in order to simplify and optimize procurement by monitoring procurement of goods, works, services to meet state and municipal needs.

Based on the information posted in the Unified Information System in the field of procurement [11], as well as in the "State Order of the Oryol Region" automated information system [12], the authors have analyzed and summarized the data in the tables below.

According to the data of [11], the analysis of the information presented in (Table I) has been carried out.

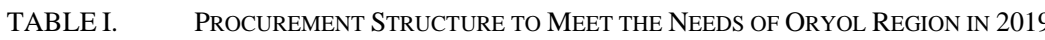

\begin{tabular}{|c|c|c|c|c|}
\hline Procurement methods & $\begin{array}{l}\text { Procurement volume } \\
\text { (IMCP), million rubles }\end{array}$ & $\begin{array}{c}\text { Number of } \\
\text { procedures, pc. }\end{array}$ & $\begin{array}{c}\text { Savings (under } \\
\text { contracts), million rubles }\end{array}$ & $\begin{array}{l}\text { Share of total } \\
\text { volume, in \% }\end{array}$ \\
\hline Total, including & 24197.6 & 28367 & 796.4 & 100.0 \\
\hline - electronic auction & 21782.8 & 25139 & 780.0 & 97.9 \\
\hline - competitions (open, with limited participation, two-phase) & 37.1 & 38 & - & - \\
\hline - request for quotations and proposals & 129.5 & 1023 & 16.4 & 2.1 \\
\hline - sole supplier (contractor, executive) & 1383.6 & 20 & - & - \\
\hline
\end{tabular}

Therefore, the total volume of purchases (the sum of the initial maximum contract price) in 2019 amounted to 24.2 billion rubles. The main part of procurement procedures was carried out using the electronic auction method - 25139 pieces, as a result of which budget savings amounted to 780.0 million rubles or $97.9 \%$ of the total volume. Savings based on the results of the request for quotations and proposals amounted to 16.4 million rubles or $2.1 \%$.

According to the monitoring conducted by the Office of Public Procurement of Oryol Region, the information is presented in (Table II).

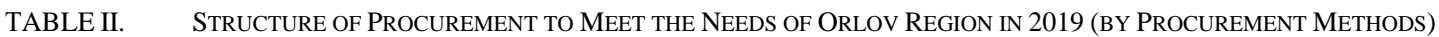

\begin{tabular}{|c|c|c|c|}
\hline Procurement methods & $\begin{array}{c}\text { Procurement volume, million } \\
\text { rubles }\end{array}$ & $\begin{array}{c}\text { Number of procedures, } \\
\text { pc. }\end{array}$ & $\begin{array}{c}\text { Share of total volume, in } \\
\%\end{array}$ \\
\hline Total, including & 14022.4 & 48405 & 100.0 \\
\hline - electronic auction & 11729.9 & 10190 & 83.7 \\
\hline - competitions (open, with limited participation, two-phase) & 45.5 & 8 & 0.3 \\
\hline - request for quotations and proposals & 195.5 & 1125 & 1.4 \\
\hline - sole supplier (contractor, executive) & 2051.3 & 37082 & 14.6 \\
\hline
\end{tabular}


The total volume of purchases in 2019 amounted to 14.0 billion rubles. According to the given data, the volume of purchases is carried out using the electronic auction method $83.7 \%$, which shows the advantage and extent of bidding carried out this way. Purchases from a sole supplier and requests for quotations (proposals) amounted to $14.6 \%$ and $1.4 \%$, respectively.

The performance of contracts concluded as a result of procurement to meet the state needs of Oryol Region in 2019 is discussed in (Table III).

TABLE III. Performance of Contracts Concluded as a Result of Procurement to MeEt State NeEds of THE ORLOV Region IN 2019

\begin{tabular}{|l|c|c|c|c|}
\hline \multicolumn{1}{|c|}{ Public contracts } & Value, million rubles & Share in the total value, in \% & Number, pc. & Share of total number, in \% \\
\hline Signed total, including & 10230.9 & 100.0 & 54823 & 100.0 \\
\hline - performed & 5572.9 & 54.47 & 40194 & 73.32 \\
\hline - canceled & 415.9 & 4.07 & 1136 & 2.07 \\
\hline - being performed total, including & 4242.1 & 41.46 & 39493 & 24.61 \\
\hline \multicolumn{1}{c|}{ term of contract is not over } & 3705.5 & 36.22 & 9552 & 7.19 \\
\hline term of contract is over & 536.6 & 5.24 & 17.42 \\
\hline
\end{tabular}

The analysis of the above data shows that $73.32 \%$ of the total number of concluded contracts have been performed, while the budget funds implementation has been completed only by $54.47 \%$. There are contracts being performed (for example, long-term construction of facilities), their share of number and value is $7.19 \%$ and $36.22 \%$, respectively. Also, the table shows canceled contracts $-2.07 \%$ and contracts with an unfulfilled term of obligations $-17.42 \%$, their presence reduces efficiency and leads to risks of spending budget funds.

The value of concluded contracts and budget savings based on the results of the biddings held are presented in (Table IV).

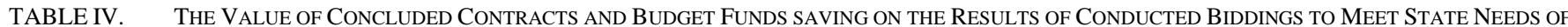
OROYL REGION IN DYNAMICS

\begin{tabular}{|c|c|c|c|c|c|c|}
\hline \multirow{2}{*}{ Indicator name } & \multicolumn{5}{|c|}{ Years } & \multirow{2}{*}{$\begin{array}{l}\text { Growth rate in } 2019 \\
\text { compared to } 2015, \%\end{array}$} \\
\hline & 2015 & 2016 & 2017 & 2018 & 2019 & \\
\hline Contract value, billion rubles & 6.9 & 5.3 & 7.7 & 7.7 & 10.2 & 147.8 \\
\hline Budget savings, million rubles & 409.4 & 531.4 & 532.8 & 374.8 & 669.1 & 163.4 \\
\hline
\end{tabular}

According to the data presented, there is a significant increase in the value of contracts and budget savings over a 5year period. Therefore, the growth rate in 2019 compared to 2015 was $147.8 \%$, which shows an increase in the volume of procurement and, as a result, the number and value of government contracts. Moreover, the growth rate of budget savings is $163.4 \%$, which increases the efficiency of budget spending.

The value of procurement and budgetary funds savings for the range of products to meet the needs of Oryol region are considered in (Table V).

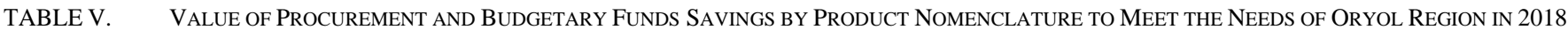

\begin{tabular}{|c|c|c|c|c|}
\hline Product range & IMCP, million rubles & Contract value, in \% & Savings, pc. & Savings of total volume, $\%$ \\
\hline Road repair & 3376.8 & 3341.4 & 35.5 & 1.1 \\
\hline Food products & 292.2 & 228.2 & 64.1 & 21.9 \\
\hline Medical goods & 630.6 & 552.7 & 77.9 & 12.4 \\
\hline Pharmaceutical products & 1248.1 & 1202.7 & 45.4 & 3.6 \\
\hline Medical equipment & 380.4 & 358.6 & 21.7 & 5.7 \\
\hline Construction & 221.8 & 214.9 & 6.8 & 3.1 \\
\hline Vehicles & 110.0 & 100.6 & 9.4 & 8.6 \\
\hline Services & 1590.9 & 1496.6 & 94.3 & 5.9 \\
\hline Other & 208.8 & 189.1 & 19.5 & 9.3 \\
\hline Total & 8059.6 & 7684.8 & 374.6 & 4.6 \\
\hline
\end{tabular}

Budgetary funds savings have amounted to 374.6 million rubles or $4.6 \%$ of total procurement volume. Analysis of the data shows that the largest share of savings is accounted for by food -64.1 million rubles or $21.9 \%$. Savings on medical 
supplies have brought 77.9 million rubles (12.4\%) to the budget, on vehicles -9.4 million rubles $(8.6 \%)$, on services and medical equipment -94.3 million rubles $(5.9 \%)$ and 21.7 million rubles $(5.7 \%)$ respectively. Savings on road repair and construction, including the building materials procurement, the savings have amounted to 35.5 million rubles $(1.1 \%)$ and 6.8 million rubles $(3.1 \%)$ respectively.

The authors pay special attention to the analysis of the amount of savings on food products -64.1 million rubles $(21.9 \%)$. Having analyzed the information presented in the "State Order of Oryol Region" automated information system, it can be seen that the winners of tenders for the supply of food products for social institutions are often organizations and individual entrepreneurs whose activities are not products production, that is, intermediaries who purchase products and offer at auctions at a price lower than that of the manufacturer. In this situation, the question about the quality of the products offered and supplied to social institutions, especially kindergartens, arises.

According to the results of the audit conducted by the Control and Accounts Chamber of Oryol Region, violations of the legislation on the contract system in the field of procurement, in particular procurement prices, have been found. So, for commodity items (milk, butter, cottage cheese) in audited budgetary institutions, procurement prices have been more than $30 \%$ below market ones [13]. The purchase of food products at prices significantly lower than market prices casts doubt on their conformity to consumer properties (safety, compliance with standards, etc.). However, institutions do not carry out an examination of food products with the involvement of an expert organization.

The contract system in the field of procurement is based on principles, one of which is the competition principle, aimed at creating equal conditions for ensuring competition between procurement participants. Competition in procurement should be based on complying the fair price principle and non-price competition between procurement participants in order to identify the best conditions for the supply of goods, performance of work and provision of services [14].

At present, in world practice, questions about the food safety of the food consumed by the population are becoming more acute. At the heart of which issues of transiting to organic agriculture and the producing ecological food are discussed, including the "green procurement" within the ecofriendly economy of the future $[15,16]$.

\section{CONCLUSION}

The public procurement market has achieved significant results over the years of its implementation in Oryol region. The volume of procurement in the region has generally increased. Therefore, in 2019 compared to 2015 it increased by 3353.5 million rubles. Most of the procurement volume is carried out through an electronic auction $83.6 \%$.

The performance of the concluded contracts based on the bidding results is $73.3 \%$ of the total number of contracts. Budget funds are not fully implemented during the year, as there are long-term contracts with carry-over, as well as canceled contracts or the contracts the term of which has expired, and, as a result, they have not been paid on time.
Most of the budget funds were allocated for road repair 3.4 billion rubles, the purchase of medicines -1.2 billion rubles and services -1.6 billion rubles.

The Public Procurement Department of Oryol Region fulfills the principle of the contract system effectiveness budget savings, during the period from 2015 to 2019 the savings have increased by 260.0 million rubles. The highest level of savings has been achieved for food products $-21.9 \%$.

Therefore, government procurement for Oryol enterprises becomes an opportunity to participate in the government procurement market, and government contracts become a serious source of income and a tool for further development.

\section{Acknowledgment}

The article was prepared with the support of the RFBR grant 17-02-00453 - OGN (RHSF 2017, competition A) "Development of a methodology for the formation and development of intraregional (municipal) clusters in the territory of advanced socio-economic development of a singleindustry town".

\section{References}

[1] D.A. Medvedev, "Russia-2024: The Strategy of Social and Economic Development", Voprosy Ekonomiki, 2018, vol. 10, pp. 5-28. (In Russ.) DOI: https://doi.org/10.32609/0042-8736-2018-10-5-28

[2] The Concept of increasing the efficiency of budget expenditures in 2019-2024 [Kontseptsiya povysheniya effektivnosti byudzhetnykh raskhodov v 2019-2024 godakh], approved by the order of the Government of the Russian Federation January 31, 2019 No 117-p. (In Russ.). $\quad$ Retrieved from http://www.consultant.ru/document/cons_doc_LAW_317187/d5887f037 ec048b8f130ba0d80ed2e57d47a3d1e/

[3] M. Dabrowski, "Factors determining Russia's long-term growth rate", Russian Journal of Economics, 2019, vol. 5, pp. 328-353. DOI: https://doi. 10.32609/j.ruje.5.49417

[4] V. Mau, "Global trends and national goals: Russia approaches a new model of economic growth", Russian Journal of Economics, 2019, vol. 5, pp. 27-45. DOI: https://doi. 10.32609/j.ruje.5.35234

[5] B. Lenderink, J.I.M. Halman, and J.T. Voordijk, "Innovation and public procurement: from fragmentation to synthesis on concepts, rationales and approaches", Innovation: The European Journal of Social Science Research, 2019. DOI: https://doi.org/10.1080/13511610.2019.1700101

[6] G. de Rassenfosse, A. Jaffe, and E. Raiteri, "The procurement of innovation by the U.S. government", PLoS ONE, 2019, vol. 14(8). DOI: https://doi.org/10.1371/journal.pone.0218927

[7] B.J. Baldus, and L. Hatton, "U.S. chief procurement officers' perspectives on public procurement", Journal of Purchasing and Supply Management, 2019, vol. 26(1). https://doi.org/10.1016/j.pursup.2019.05.003

[8] The Federal Acquisition Regulation (FAR), 2020. Retrieved from https://www.acquisition.gov/

[9] Consolidated analytical report on the results of monitoring the procurement of goods, works, services to meet state and municipal needs at the end of 2019 [Svodnyy analiticheskiy otchet po rezul'tatam osushchestvleniya monitoringa zakupok tovarov, rabot, uslug dlya obespecheniya gosudarstvennykh i munitsipal'nykh nuzhd po itogam 2019 goda], 2020. (In Russ.). Retrieved from https://www.minfin.ru/common/upload/library/2020/06/main/Svodnyy_a naliticheskiy_otchet_2019.pdf

[10] Decree of the Government of the Oryol Region dated September 13, 2019 No 522 "On monitoring the procurement of goods, works, services to meet the state needs of the Oryol region" ["O monitoringe zakupok tovarov, rabot, uslug dlya obespecheniya gosudarstvennykh nuzhd Orlovskoy oblasti'], 2019. (In Russ.). Retrieved from http://docs.cntd.ru/document/561539108

[11] Unified Information System in the field of procurement [Edinaya informatsionnaya sistema v sfere zakupok], 2020. (In Russ.). Retrieved 
from http://www.zakupki.gov.ru

[12] Automated Information System "State Order of the Oryol Region" ["Gosudarstvennyi zakaz Orlovskoy oblasti" Avtomatizirovannaya informatsionnaya sistema], 2020. (In Russ.). Retrieved from http://www.goszakupki-orel.ru/

[13] Report on the activities of the Chamber of Control and Accounts of Oryol Region in 2018 [Otchet o rabote Kontrol'no-schetnoy palaty Orlovskoy oblasti za 2018 god], 2019. (In Russ.). Retrieved from http://www.ksp-orel.ru/otchety-o-deyatelnosti/

[14] Federal Law of 05.04.2013 No 44-FZ "On the contract system in the field of procurement of goods, works, services to meet state and municipal needs" ["O kontraktnoy sisteme v sfere zakupok tovarov, rabot, uslug dlya obespecheniya gosudarstvennykh i munitsipal'nykh nuzhd"], 2013. (In Russ.). Retrieved from http://www.consultant.ru/document/cons_doc_LAW_144624/

[15] Y. Dou, Q. Zhu, and J. Sarkis, "Green multi-tier supply chain management: An enabler investigation", Journal of Purchasing and Supply Management, 2017, vol. 24(2), pp. 95-107. DOI: 10.1016/j.pursup.2017.07.001

[16] Z. Jouzi, H. Azadi, F. Taheri, K. Zarafshani, K. Gebrehiwot, S. van Passel, and P. Lebailly, "Organic Farming and Small-Scale Farmers: Main Opportunities and Challenges", Ecological Economics, 2017, vol. 132, pp. 144-154. DOI: 10.1016/j.ecolecon.2016.10.016 